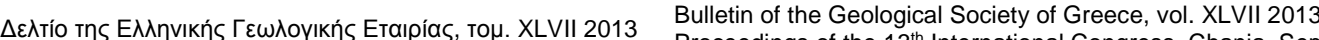
Proceedings of the $13^{\text {th }}$ International Congress, Chania, Sept.

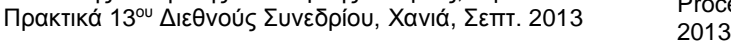

\title{
INFLUENCE OF GEOLOGICAL AND GEOTECHNICAL CONDITIONS TO DESIGN A WATER RESERVOIR IN KARST AREA
}

\author{
Steiakakis E. ${ }^{1}$, Vafidis A. ${ }^{1}$, Manoutsoglou E. ${ }^{1}$ and Vavadakis D. ${ }^{1}$ \\ ${ }^{1}$ Technical University of Crete, Department of Mineral Resources Engineering, \\ stiakaki@mred.tuc.gr,vafidi@mred.tuc.gr,emanout@mred.tuc.gr,vavadaki@mred.tuc.gr
}

\begin{abstract}
The design of a water reservoir in a site underlain by karstified carbonate rocks, encounters many difficulties mainly due to unpredictable location, dimensions and geometry of the karst structure and voids.

The objective of this work is to present part of the investigation work that was carried out in Omalos plateau (W. Crete) where a water reservoir is going to be constructed.

The survey was based on geological mapping, geophysical exploration, boreholes drilling, sampling and laboratory testing for the geotechnical parameters determination.

The soil thickness that is required to provide stability against soil collapse into voids and the subsequent formation of sinkholes was estimated.

The evaluations represent a useful decision-support tool in the management of the investigation results for the design purposes of the water reservoir in Omalos plateau.
\end{abstract}

Key words: Karst, sinkholes, geotechnical investigation.

\section{Пєрí $\eta \psi \eta$}

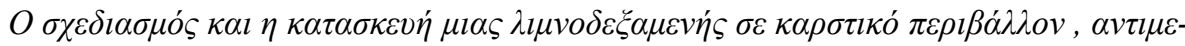

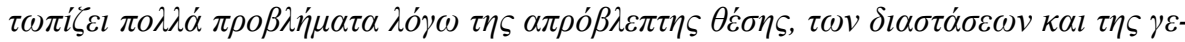

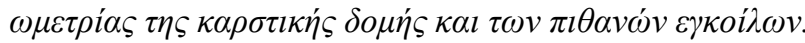

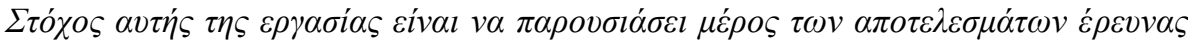

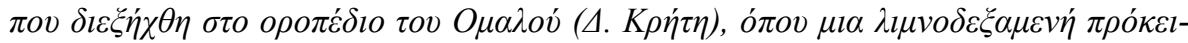

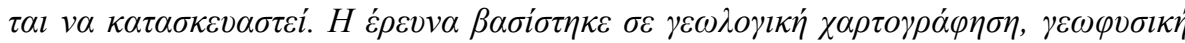

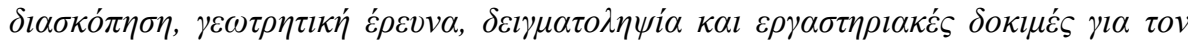

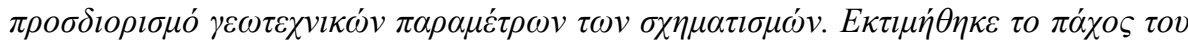

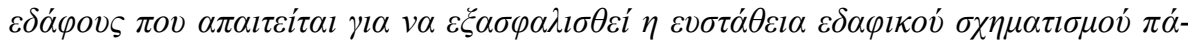

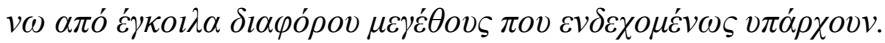

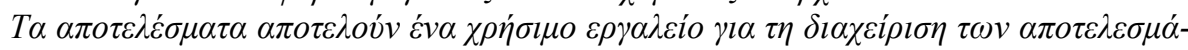

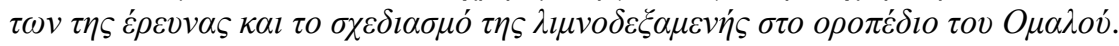

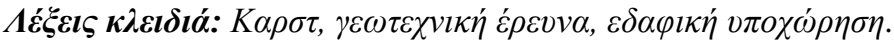

\section{Introduction}

Omalos plateau encompasses an area of approximately $6 \mathrm{~km}^{2}$. It lies in a distance of $45 \mathrm{~km} \mathrm{S-SW}$ of Chania city (Figure 1), at an altitude of about 1,050 m asl.

XLVII, No $3-1892$ 


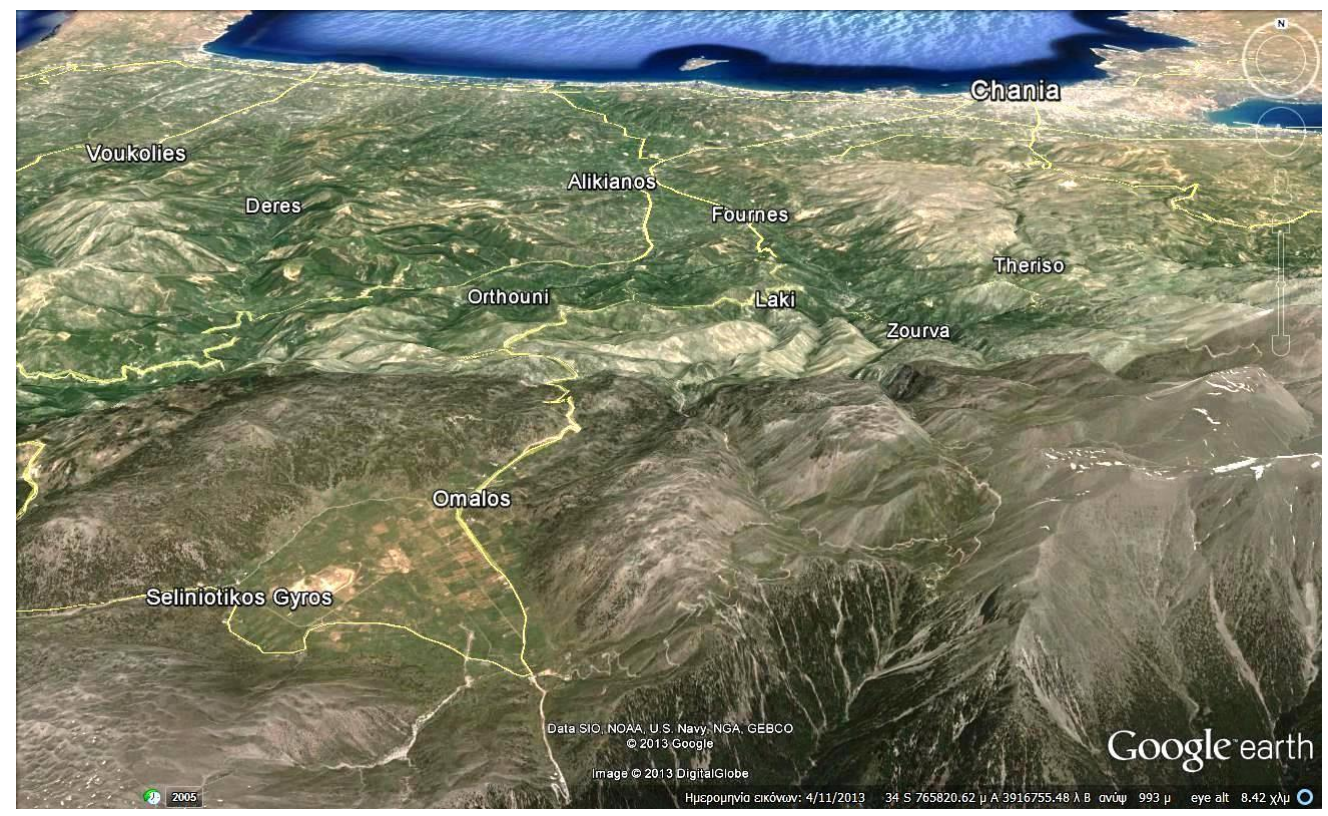

Figure 1 - Omalos Plateau.

The surface profile in Omalos plateau appears to be smooth, with elevation differences not higher than $15 \mathrm{~m}$.

An embankment pond is under construction in the SW part of the Plateau, North of "Seliniotikos Gyros", within the administrative boundaries of Kantanos-Selino municipality. The impounded water will be used for irrigation purposes.

The water reservoir is created partly by the construction of an embankment of maximum height of $10 \mathrm{~m}$, and partly by excavation.

According to the initial design, the inundation area is $1.97 \mathrm{~km}^{2}$ and the reservoir net capacity is estimated to $750,000 \mathrm{~m}^{3}$.

The area was investigated and evaluated in 1993 as a potential site for the water reservoir. Original approval of this site was based mainly upon its favourable topography and water-impoundment capabilities of the area. However, this decision did not adequately consider the geology in depth.

In 2012, a second exploration was conducted. The stability of the soil formations that overlie the solution cavities was a concern during the latter research. Based on the investigation results, the soil thickness that is required to provide stability against soil collapse into possible underlying cavities was estimated.

The results can be used to evaluate the stability of the candidate site for a range of anticipated sizes of voids.

\section{Evolution of Sinkholes}

Two types of mechanisms are responsible for the development of sinkholes in a site underlain by carbonate rocks.

The first, and by far the most common, is an upward ravelling of soil over a cavity in the bedrock (Sowers, 1978 as stated by Adams and Lovell, 1984).

Figure 2 shows the development of a sinkhole over an opening in the rock, which may be a small cave, an enlarged joint or fracture, or a narrow vertical pipe. As has been ascertained, in sandy

$\underline{\text { XLVII, No } 3-1893}$ 
soils surface subsides slowly. On the other hand, in clay soils cavity forms first at rockhead, then grows in size until cohesive soil bridge fails, to cause sudden dropout collapse of surface (Waltham, 2002).

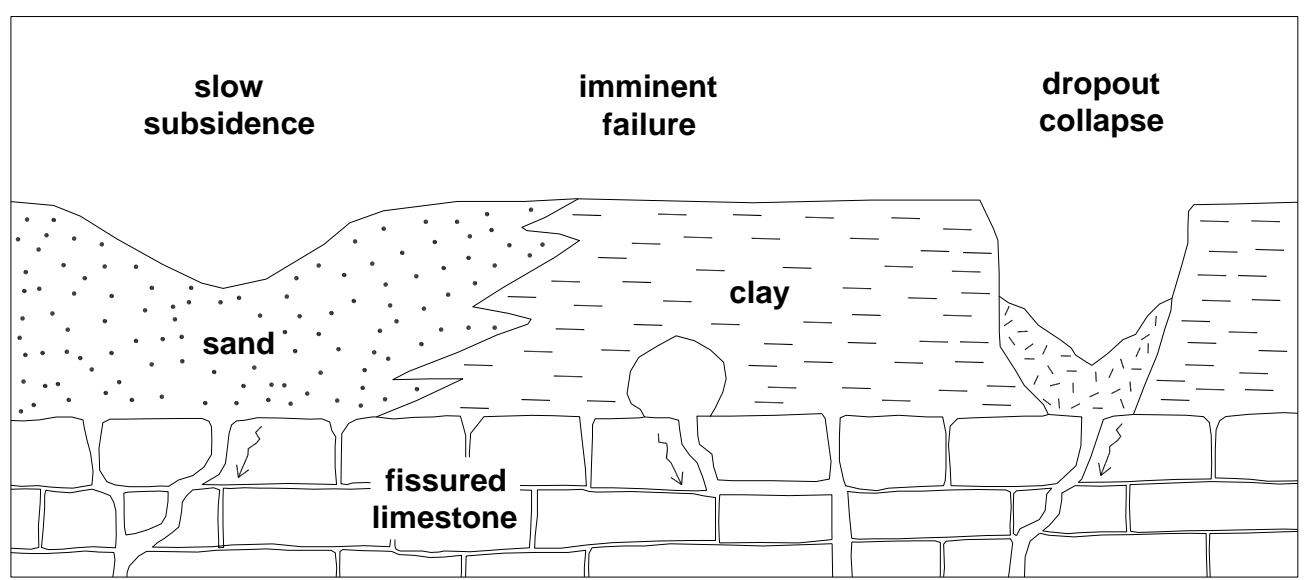

Figure 2 - Schematic of sinkhole development (Waltham, 2002, modified).

It is worth noting that groundwater fluctuations may enlarge the void over time. Particularly, the shear strength of the soil is weakened as it becomes saturated. When the water level drops again, the effective stress increases, and soil ravelling occurs as the stresses are redistributed. If the thickness of the stronger soil above the void is insufficient for arching to develop, the soil above the dome will fail, resulting in a depression at the surface in the form of a doline.

The second mechanism responsible for sinkhole development is collapse of the soil and rock roof above a cavity. Such a phenomenon is rare, however (Adams, and Lovell, 1984).

As has been documented by the literature, ravelling failures are the most widespread and probably the most dangerous of all the subsidence phenomena associated with karstic carbonate rocks.

Furthermore, thicker soil covers develop fewer subsidence sinkholes. As stated by Waltham (2005), China has many thousands of recorded subsidence sinkholes, and data from different areas within the karst indicate that over $60 \%$ of sinkholes occur in cover soils less than $5 \mathrm{~m}$ thick and over $85 \%$ in cover less than $10 \mathrm{~m}$ thick. A similar picture appears in East Tennessee, where about $70 \%$ of the sinkholes surveyed had overburden thickness less than $10 \mathrm{~m}$ (Newton and Tanner, 1986).

Moreover, a similar trend has occurred in Florida, where most sinkholes occur in cover less than $20 \mathrm{~m}-30 \mathrm{~m}$ thick. Only where soil cover is more than $60 \mathrm{~m}$ thick sinkholes are described as very rare (Waltham, 2005).

\section{Geological Layout}

The geological section defined in Figure 3, present the geological structure in the study area. It was constructed with base the published geological maps (Tataris and Christodoulou 1969) and the geological survey realized in the area.

The Omalos Plateau is underlain by karstic carbonate rocks of Trypali unit. Trypali unit overlies the system of Plattenkalk limestone, and it forms a separate hydrogeological entity in the area with intensive karstification.

The overlying Quaternary alluvium is considered to be the result of several depositional events of the wide alluvial fans. It covers an extensive area of Omalos plateau and it constitutes the subsurface of the embankment pond. The field investigation showed that karstic features such as

XLVII, No 3 - 1894 
dolines are prominent in the wider region, mainly in the northern portion of the Plateau, outside the reservoir perimeter.

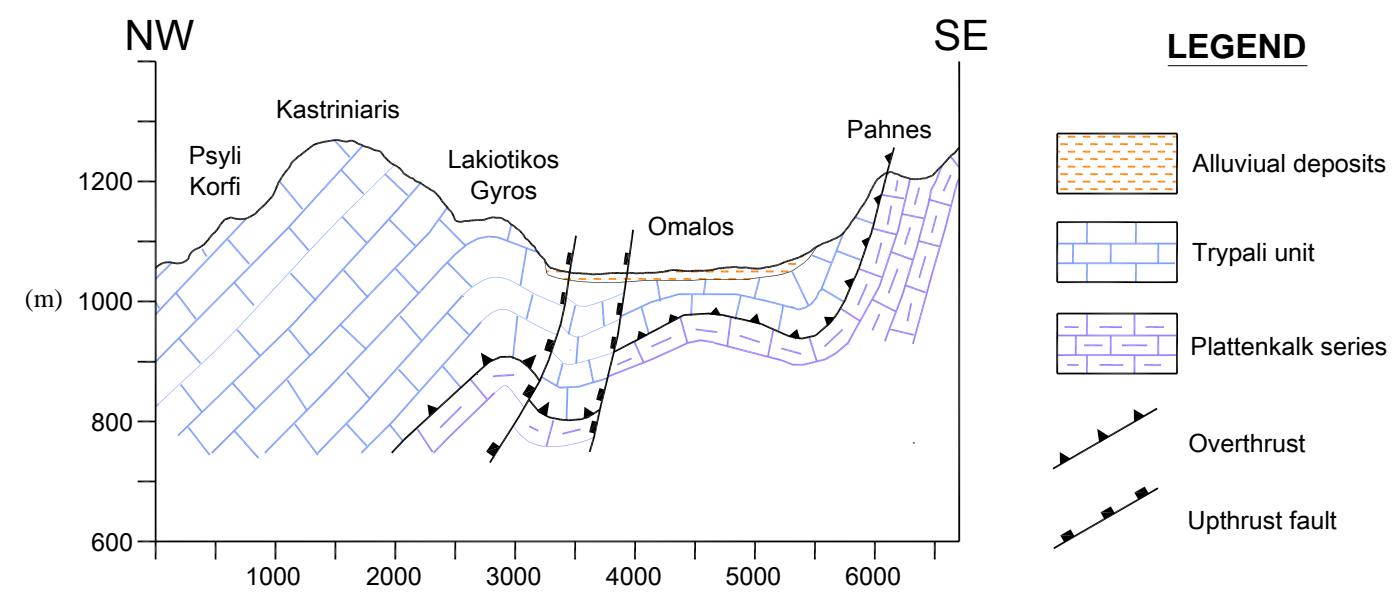

Figure 3 - Schematic geological section (Steiakakis et al., 2011, modified).

The plateau is dissected by a number of north-south trending normal faults.

These faults play an important role in the formation of sinkholes, but mainly they contribute to the enlargement of the voids over the groundwater water table, and their evolution towards higher elevations (ground surface). This is because the surface runoff water easily infiltrates fault zones, increasing the unit weight of dry soil and inducing seepage forces. Furthermore, the increase in saturation reduces suction in the unsaturated soil voids, which decreases the effective stress and the strength of the soil above the cavity (Zhiqiang Yang M., Drumm E., 2002).

From the hydrogeological point of view, perched water table lies within the gravely sands (bordered by the underlying silty - clayey layers) of the alluvial formation.

\section{Geotechnical Investigation}

The geotechnical investigation included drilling and sampling of four (4) boreholes (BH1, BH2, $\mathrm{BH} 2$ and $\mathrm{BH} 4$ ) to a maximum depth of $35 \mathrm{~m}$ below existing ground surface, at the locations shown in Figure 4.

The groundwater conditions were observed in the boreholes during augering and sampling, and after completion.

In addition, a laboratory testing program consisting of moisture content, Atterberg limits, grain size analyses and shear strength determination, were carried out on selected samples.

Based on drilling exploration, the succession of the layers founded in the first $35 \mathrm{~m}$ below the ground surface, is as follows.

\section{Topsoil}

The boreholes encountered approximately $0.7 \mathrm{~m}$ to $1.0 \mathrm{~m}$ of topsoil. It should be noted that its thickness could vary considerably in between and beyond borehole locations. Thicker topsoil is normally expected in low-lying areas and water courses while topsoil is absent in the area that has been excavated for the reservoir construction purposes.

\section{Brownish-yellow sandy silty clay}

Underlying the topsoil, all boreholes except BH4 encountered a sandy silty clay formation.

\section{No $3-1895$}




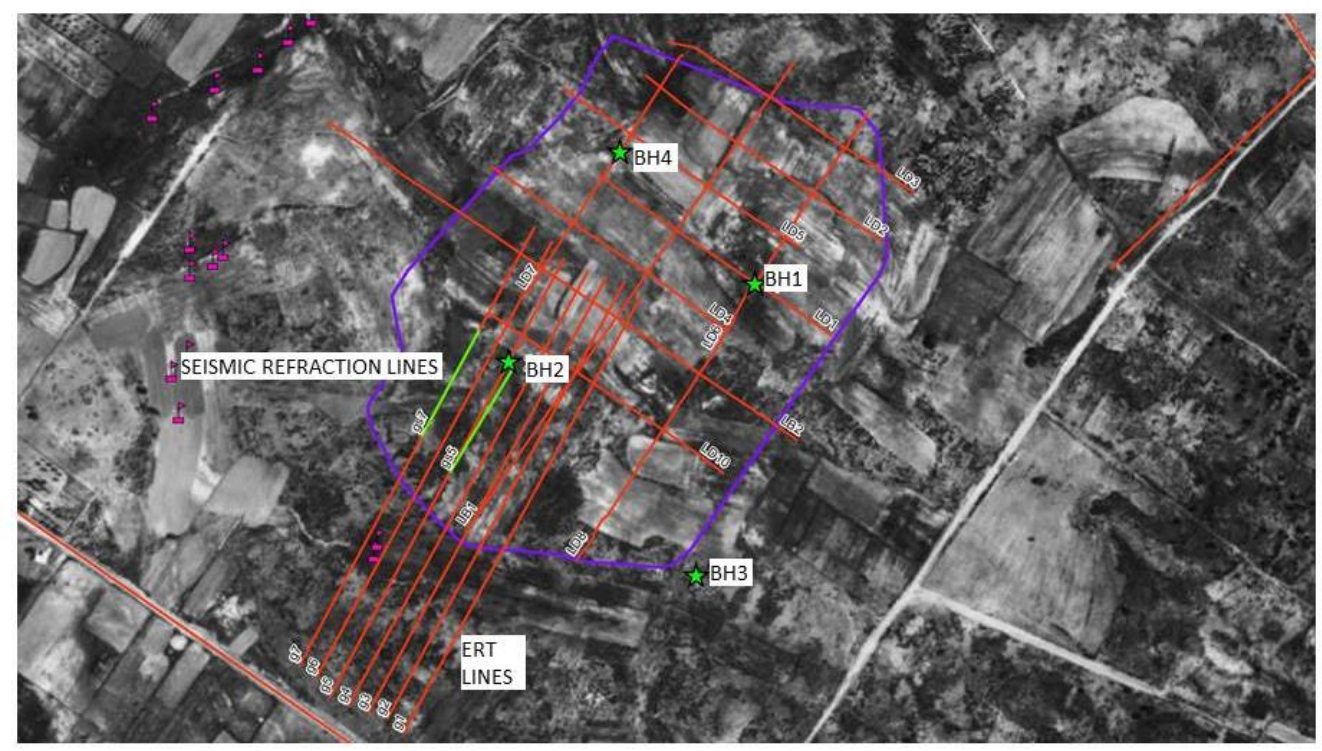

Figure 4 - Electric tomography grid (gX), Seismic refractions lines (gsX) and locations of Boreholes (BSX) in Omalos plateau.

In BH1 the layer was found to extend to the depth $13.8 \mathrm{~m}$ in $\mathrm{BH} 2$ up to $14.4 \mathrm{~m}$, in $\mathrm{BH} 3$ up to 8.5 $\mathrm{m}$ and in BH4 up to final depth of the borehole $(15 \mathrm{~m})$.

This layer is ascribed to the alluvial fan that is composed of a heterogeneous mixture of clay and silt with some sand and gravel size particles. Due to the nature of the formation, the presence of cobbles and boulders were met during drilling (BH3 5.40-8.50m depth).

It should be noted that BH1 showed signs of minor cavities in depth $6.4 \mathrm{~m}$, when the drilling was advancing just by the self-weight of the rods for several centimetres. At the same depth perched water table was detected, that lies within gravely sand layer bordered by the underlying clayey layer of the alluvial formation.

This layer is generally moist with measured moisture contents ranging between 18 and $23 \%$, and its dry unit weight estimated equal to $22 \mathrm{kN} / \mathrm{m}^{3}$.

The results of grain size analyses of samples taken from this layer showed that they contain gravel $(3-11 \%)$, sand $(4-21 \%)$, silt $(68-86 \%)$ and clay $(1-9 \%)$.

Moreover, the liquid limit estimated equal to $\mathrm{LL}=24 \%$, the plastic limit $\mathrm{PL}=20 \%$ and the plasticity index $\mathrm{PI}=4 \%$.

Based on these results the samples are classified, according to the Unified Soil Classification System (USCS), as sandy silty clay.

For the samples taken, the direct shear testing program yielded cohesion that ranges from $c^{\prime}=19.7 \mathrm{kN} / \mathrm{m}^{2}$ to $33.3 \mathrm{kN} / \mathrm{m}^{2}$ and friction angle between $\varphi^{\prime}=22$ and $32^{\circ}$.

\section{Brown Sandy - Clayey Silt layer}

Underneath the brownish-yellow sandy silty clay, encountered a brown sandy - clayey silt layer with lower moisture content. In $\mathrm{BH} 1$ and $\mathrm{BH} 2$ this layer was found to extend at depths between 14.0 and $35.0 \mathrm{~m}$ below existing ground surface, while in BH3 this deposit extends to depths between 8.5 to $23.3 \mathrm{~m}$ below existing ground surface where the carbonate formation is found.

The measured moisture content ranges between 16 and $21 \%$.

XLVII, No 3 - 1896 
The results of grain size analyses in the samples taken from this layer showed that they contain gravel (1-3\%), sand (9-11\%), silt (83\%) and clay (4-6\%).

Moreover, the liquid limit estimated equal to $\mathrm{LL}=20 \%$, the plastic limit $\mathrm{PL}=18 \%$ and the plasticity index $\mathrm{PI}=2 \%$.

Based on these results the samples are classified, according to the Unified Soil Classification System (USCS), as sandy - clayey silt.

For the samples taken, the testing program yielded cohesion ranges from $c^{\prime}=15.7 \mathrm{kN} / \mathrm{m}^{2}$ and friction angle $\varphi^{\prime}=33.8^{\circ}$.

\section{Carbonate rock formation}

Cores, from Borehole 3 showed that the karst carbonate formation founded $23 \mathrm{~m}$ below the surface; it is highly fissured and unstable. The TCR ranges between 44 and $100 \%$ and the RQD varies between $0 \%$ (in core lengths $0.2-0.7 \mathrm{~m}$ ) and $100 \%$ (in core lengths $0.2-0.5 \mathrm{~m}$ ).

\section{Groundwater Conditions}

No groundwater was encountered in boreholes on completion of all the boreholes except BH1 where groundwater was encountered at depth of about $6.5 \mathrm{~m}$ below existing ground surface.

However, it should be noted that the groundwater table could fluctuate seasonally and in response to severe weather events.

\section{Geophysical Investigation}

The geophysical survey in Omalos Plateau was conducted by employing the VES, ERT and seismic refraction methods. The former (VES method) estimates the average thickness of the alluvial deposits, while the ERT and seismic refraction methods map the relief of the underlying karstic carbonate formations.

Further interpretation of the data obtained by ERT and seismic refraction methods offered a further indication regarding the detection of subsurface cavities.

The results of the geophysical campaign fixed the variations of alluvium thickness and the depth of the carbonate rocks formation at between 25 and $40 \mathrm{~m}$. This depth also being supported by the exploratory drilling, extend down to $35 \mathrm{~m}$.

The produced map, based on the detected geophysical anomalies up to a depth of 40m, was subsequently used to outline areas of high risk regarding the presence of subsurface cavities inside the reservoir area.

Based on data collected on a grid in the south west portion of Omalos plateau, none subsurface cavity with width greater than $20 \mathrm{~m}$ was detected up to $40 \mathrm{~m}$ depth.

However, a more comprehensive geophysical exploration is necessary in order to cover the rest of the study area in detail and to detect potential smaller subsurface cavities.

\section{Stability Evaluation of a Potential Site}

The stability evaluation against soil collapse into voids was performed on the basis of the expected soil thickness and the anticipated range of soil voids.

Seven model tests were conducted to examine sinkhole development in the soil formation over cavities with different sizes.

Based on Adams and Lovell (1984) suggestion, a simplified analysis of soil stability above a developing cavity in carbonate rocks was adopted.

$\underline{\text { XLVII, No } 3-1897}$ 
The analysis is based on Terzaghi's equations for soil arching over an infinitely long void, assuming that the lateral load transfer is achieved through shear stresses along vertical planes located at the edges of the void (Figure 5).

The real surfaces of sliding, as observed by Terzaghi in 1936, are curved and at the soil surface their spacing is greater than the width of the yielding strip. However, vertical sides were assumed for simplicity. In addition, the horizontal stresses were assumed to be of the active mode, since erosion of the arch has resulted in a release of lateral pressure.

The soil layer was assumed to be horizontal and to have a uniform thickness, while the groundwater table was considered to be lower than the bottom of alluvial formation. The stress applied on the ground surface was assumed to be normal, uniformly distributed and equal to the imposed load from the reservoir project construction.

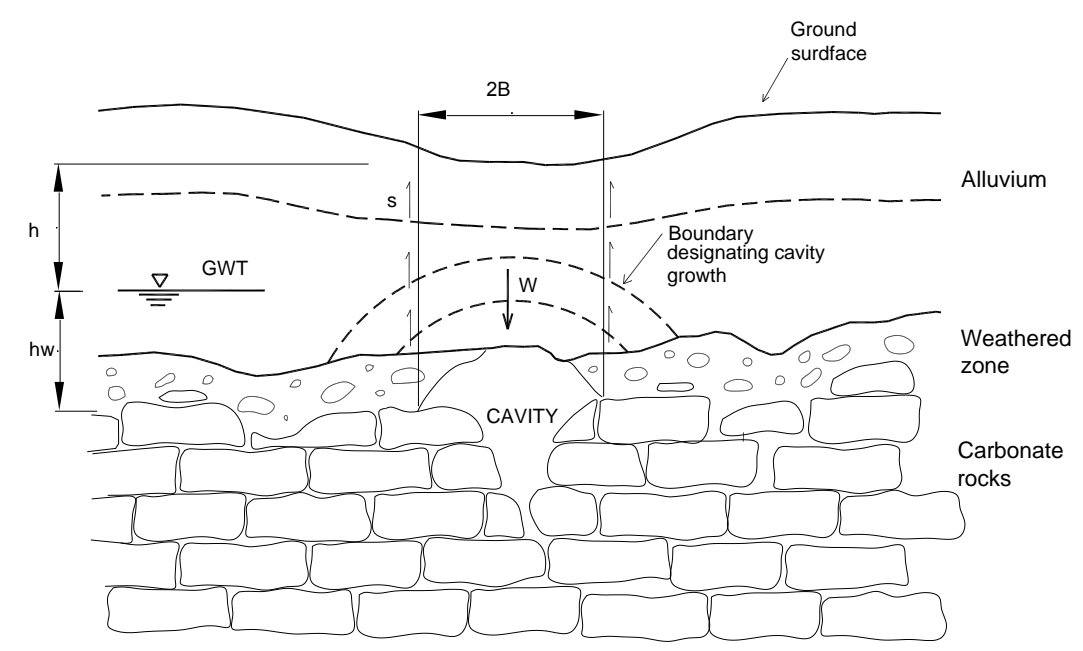

Figure 5 - Subsurface profile of a void developing in the soil formation above a solutionenlarged cavity in the bedrock (Adams and Lovell, 1984, modified).

Based on Mohr-Coulomb strength criterion, the strength (s) along vertical planes (Fig. 5), is equal to $s=c^{\prime}+\sigma_{h}^{\prime} \cdot \tan \varphi^{\prime}$ and assuming fully mobilized active earth pressure along the sides of the soil block, the shearing strength is equal to:

$s=2\left[c^{\prime}\left(h+h_{w}\right)+\left(\frac{1}{2} k_{a} \gamma h^{2}+k_{a} \gamma h h_{w}+\frac{1}{2} k_{a}\left(\gamma-\gamma_{w}\right) h_{w}^{2}\right)\right] \tan \phi^{\prime}$

where

$\mathrm{s}=$ soil shear strength in terms of effective stress

$\mathrm{c}^{\prime}=$ cohesion intercept of soil in terms of effective stress

$\sigma_{\mathrm{h}}^{\prime}=$ effective horizontal stress

$\varphi^{\prime}=$ effective angle of internal friction of soil

$\gamma=$ unit weight of the soil

$\gamma_{\mathrm{w}}=$ unit weight of the water

$\mathrm{h}=$ depth to ground water-table

$\mathrm{h}_{\mathrm{w}}=$ depth of water

$\mathrm{k}_{\alpha}=$ coefficient of lateral earth pressure

XLVII, No $3-1898$ 
The weight (W) of the block (Fig. 5) is equal to $\mathrm{W}=2 \mathrm{~B} \cdot\left[\mathrm{h} \cdot \gamma+\mathrm{h}_{\mathrm{w}} \cdot\left(\gamma-\gamma_{\mathrm{w}}\right)\right]$, where $2 \mathrm{~B}=$ width of the yielding strip.

Equating $\mathrm{s}$ and $\mathrm{W}$ (equilibrium conditions), and rearranging to solve for B yields:

$$
B=\frac{c^{\prime}\left(h+h_{w}\right)+\left(\frac{1}{2} k_{a} \gamma h^{2}+k_{a} \gamma_{m} h h_{w}+\frac{1}{2} k_{a}\left(\gamma-\gamma_{w}\right) h_{w}^{2}\right) \tan \phi^{\prime}}{h \gamma+h_{w}\left(\gamma-\gamma_{w}\right)}
$$

The required thickness of the soil to assure the stability of the soil formation over openings of different sizes was estimated and the results are presented in Table 1.

Table 1 - Relationship between void size and overburden thickness of the soil formation suficient to assure stability with respect to failure under the imposed loadings.

\begin{tabular}{|l|l|l|l|l|l|l|l|}
\hline $\begin{array}{l}\text { Overburden thickness } \\
\text { of the soil formation } \mathrm{h}(\mathrm{m})\end{array}$ & 5 & 10 & 15 & 20 & 25 & 30 & 40 \\
\hline Void size 2B $(\mathrm{m})$ & 1.15 & 2.20 & 3.22 & 4.21 & 5.20 & 6.18 & 8.12 \\
\hline
\end{tabular}

It was concluded that for the measured friction angle $\varphi^{\prime}=28^{\circ}$ and cohesion $\mathrm{c}^{\prime}=25 \mathrm{kN} / \mathrm{m}^{2}$, a soil thickness of $25 \mathrm{~m}$ over a void of $5.2 \mathrm{~m}$ width is sufficient to assure the stability. In any case, using the results of Table 1 may facilitate the dome detection by geophysical methods and define the problem sites.

However, it should be noted that the above method may lead to poor predictions because of the true, three dimensional nature of the sinkholes and because of the simplifying assumptions.

Therefore, only if the assumptions and limitations are kept in mind, this approach can be a useful tool for planning the location and the size of the reservoir out of the problem areas.

The risk assessment can be determined more accurately taking further geotechnical and geophysical survey and simulating local conditions through finite element software. This simulation will help in predicting the potential movement of the subsoil in various positions of the project.

\section{Conclusions and Discussion}

The geological model of the study area shows that the Quaternary alluvial mainly constitute the subsurface of the water reservoir site with a thickness variable from more than $25 \mathrm{~m}$ in the western portion, to $40 \mathrm{~m}$ in the eastern sector of the site where is placed the water reservoir.

Karstic features such as dolines are prominent in the region, mainly in the northern portion of Omalos Plateau, outside the reservoir perimeter.

Sudden occurrence of sinkholes can be resulted from collapse of the roof of a cavity to its progressive enlargement in size until cohesive soil bridge fails. The evaluation of the soil thickness that is required to provide stability against soil collapse into underlying openings and the subsequent formation of sinkholes represents a useful decision-support tool in the management of the investigation results for the design of the water reservoir.

It should be noted that in any case, the position and variability of the water table is a key aspect in sinkhole development since it affects the stresses acting on the soil and rock. For this reason, it is required an increased protection from leaks of the reservoir. It is necessary to ensure the proper construction of an extensive network of drains (if possible impervious to their base) in order to prevent any infiltration into the subsoil. 
It is advisable to execute additional drilling - geotechnical investigation particularly in sites where geophysical survey indicates that the underground void has an opening that does not assure stability according to the estimations.

\section{References}

Adams F.T. and Lovell C.W. 1984. Geotechnical Engineering Problems in the Karst Region of SouthernIndiana. Publication FHWA/IN/JHRP-84/12, Joint Highway Research Project, Indiana Department of Transportation and Purdue University, West Lafayette, Indiana, 1984. doi: $10.5703 / 1288284314078$

Newton J. G.1976. Early detection and correction of sinkhole problems in Alabama, with a preliminary evaluation of remote sensing applications: Alabama Highway Department, Bureau Research and Development, Research Report no. HPR-76, 83 p.

Newton J. G. 1984. Natural and induced sinkhole development in the Eastern United States. U.S. Geological Survey, Tuscaloosa, Alabama. Available online at: http://iahs.info/redbooks/a151/iahs_151_0549.pdf.

Newton J. G. and Tanner J. M. 1986. Regional inventory of karst activity in the Valley and Ridge Province, Eastern Tennessee, Phase 1. Oak Ridge National Laboratory ORNL/Sub/11$79811 / 1$

Sowers G.F. 1978. Mechanisms of Subsidence Due to Underground Openings, Subsidence Over Mines and Caverns, Moisture and Frost Actions, and Classification, TRB, Transportation Research Record , 612, 2-8 pp.

Steiakakis E. Monopolis D. Vavadakis D. and Manutsoglu E. 2011. Hydrogeological research in Trypali carbonate Unit (NW Crete). ${ }^{\text {9th }}$ International Hydrogeological Congress. 5-8 October 2011. N. Lambrakis et al. (Eds.), Advances in the Research of Aquatic Environment, Vol. 1. DOI 10.1007/978-3-642-19902-8, Springer-Verlag Berlin Heidelberg 2011. pp. 561567.

Tataris A. and A. Christodoulou G. E. 1969. Geological map of Greece, sheet Alikianou, scale 1:50,000, Institute for Geology and Subsurface Research.

Waltham T. 2002. Foundations of Engineering Geology, 2nd Edition. Spon press. Taylor and Francis Group.

Waltham T. Bell and F. G., Culshaw M. G. 2005. Sinkholes and Subsidence: Karst and Cavernous Rocks in Engineering and Construction. Praxis Publishing Ltd, Chichester, UK.

Zhiqiang Yang and M., Drumm Eric C. 2002. Stability evaluation for the siting of municipal landfills in karst. Engineering Geology 65, pp.185-195. 